\begin{tabular}{l|c|c}
\hline ISSN: 0001-5113 & ACTA ADRIAT., & SHORT COMMUNICATION \\
AADRAY & $61(2): 185-190,2020$ & \\
\hline
\end{tabular}

\title{
Occurrence of the Blue Button Porpita porpita (Linnaeus, 1758) in the Iskenderun Bay, Northeastern Mediterranean Coast of Turkey
}

\author{
Mevlüt GÜRLEK ${ }^{1}$, Ali UYAN ${ }^{1 *}$, Servet A. DOĞDU ${ }^{1}$, Serpil KARAN ${ }^{1}$, \\ Ahmet GÖKÇEN ${ }^{2}$ and Cemal TURAN ${ }^{1}$ \\ ${ }^{1}$ Molecular Ecology and Fisheries Genetics Laboratory, Marine Science Department, Faculty of \\ Marine Science and Technology, Iskenderun Technical University, \\ 31220 Iskenderun, Hatay, Turkey
}

${ }^{2}$ Department of Electrical and Electronics Engineering, Faculty of Electrical and Electronics, Iskenderun Technical University, 31220 Iskenderun, Hatay, Turkey

*Corresponding author, e-mail: ali.uyan.mfbe15@iste.edu.tr

The blue button Porpita porpita (Linnaeus, 1758) was observed for the first time in July 2018 in the Iskenderun Bay, Northeastern Mediterranean coast of Turkey. This is the third record of this species for Turkish marine waters, while it is the first record for Iskenderun bay. The presence of P. porpita in the northeastern Mediterranean coast of Turkey shows its extension from northwestern Mediterranean coast (Antalya Bay) of Turkey.

Key words: Porpita porpita, Hydrozoan, Iskenderun Bay, Turkish Marine Waters

\section{INTRODUCTION}

During the last two decades in the eastern Mediterranean coasts of Turkey, a large number of hydrozoan species as non-indigenous have been reported (TURAN et al., 2011; GÜRLEK et al., 2013; ERGÜDEN et al., 2014; GÜLŞAHIN et al., 2016).

Porpitidae family (chondrophores) is represented by two genera Porpita and Velella, both of which are found in the Mediterranean Sea (GUERRERO et al., 2016; FURFARO et al., 2017; SAYGIN, 2017; WORMS, 2018). The genus Porpita has only one species Porpita porpita (WORMS, 2018).
The blue button Porpita porpita (LINNAEUS, 1758) is a colonial Hydrozoa belonging to the Porpitidae family. The species was defined by LINNAEUS (1758) as Medusa porpita. Although numerous nominal species under the Porpita genus have been proposed, the overall have been now gathered under one roof now as synonyms of Porpita porpita (CALDER, 1988; SCHUCHERT, 2013).

Blue button is a marine organism consisting of a colony of hydroids. These hydroids live on the ocean surface, are sometimes blown into shore and thousands of them can be seen. Blue button feeds on plankton and other small 
organisms, whereas they are typically eaten by sea slugs and violet sea snails. Blue buttons are hermaphrodites and have reproductive polyps that release eggs and sperms into the water. The eggs are fertilized and turn into larvae, which develop into individual polyps step by step. Blue button is actually colonies of different types of polyps; these colonies form when a polyp divides to form new types of polyps. The polyps are specialized for different functions, such as reproduction, feeding, and defense (PANDYA et al., 2013).

P. porpita has an unnoticeable sting that do not pose health risks for humans (GERSHWIN et al., 2010), therefore, the blue button is almost harmless since its tentacles might only give rise to some irritation for human skin. Recently, it has been found to contain bioactive compounds having antimicrobial effect (FREDRICK \& RAVICHANDRAN, 2010).

$P$. porpita is found in the Atlantic and IndoPacific Oceans (MEINKOTH, 1981; GUL \& GRAVILI, 2014; CHOWDHURY et al., 2016). In the Mediterranean, $P$. porpita was reported from the eastern to the western coasts, including the Syrian coasts (MAMISH et al., 2019), the Ionian and Adriatic Sea (LILLO et al., 2019), the Maltese coasts (DEIDUN, 2010), the Tyrrhenian Sea (FURFARO et al., 2017), the Corsican Sea (KOUSTENI et al., 2019) and the Balearic Sea (GUERRERO et al., 2016). In Turkish marine waters, $P$. porpita was recorded for the first time from Lycia (today's Teke Pennisula) in February 1842 (FORBES, 1844) in the western Mediterranean coast of Turkey. Subsequently,

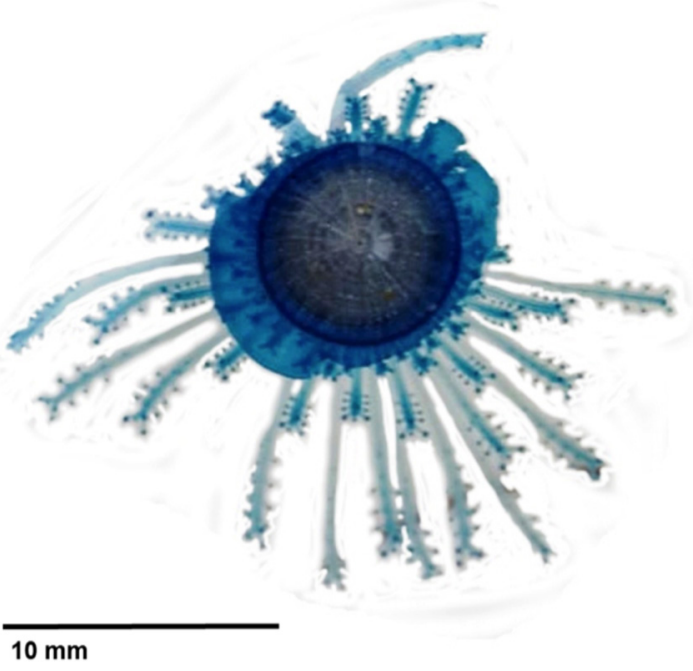

Fig. 2. Porpita porpita from Iskenderun Bay, Northeastern Mediterranean

this species was reported as second time from the Antalya Bay (Gazipaşa coast) on 14 July 2016 by SAYGIN (2017).

The present study reports the occurrence of P. porpita in the Iskenderun Bay, from the northeastern Mediterranean coast of Turkey.

\section{MATERIAL AND METHODS}

A single specimen of P. porpita was observed which came ashore, it was put in a bucket and photographed in 19 July 2018 from the Iskenderun Bay, northeastern Mediterranean coast of Turkey (3649' 754" N, 35 96' 953" E), (Fig. 1). The disc length of single specimen was $8 \mathrm{~mm}$ and the length with tentacles was $25 \mathrm{~mm}$ (Fig.

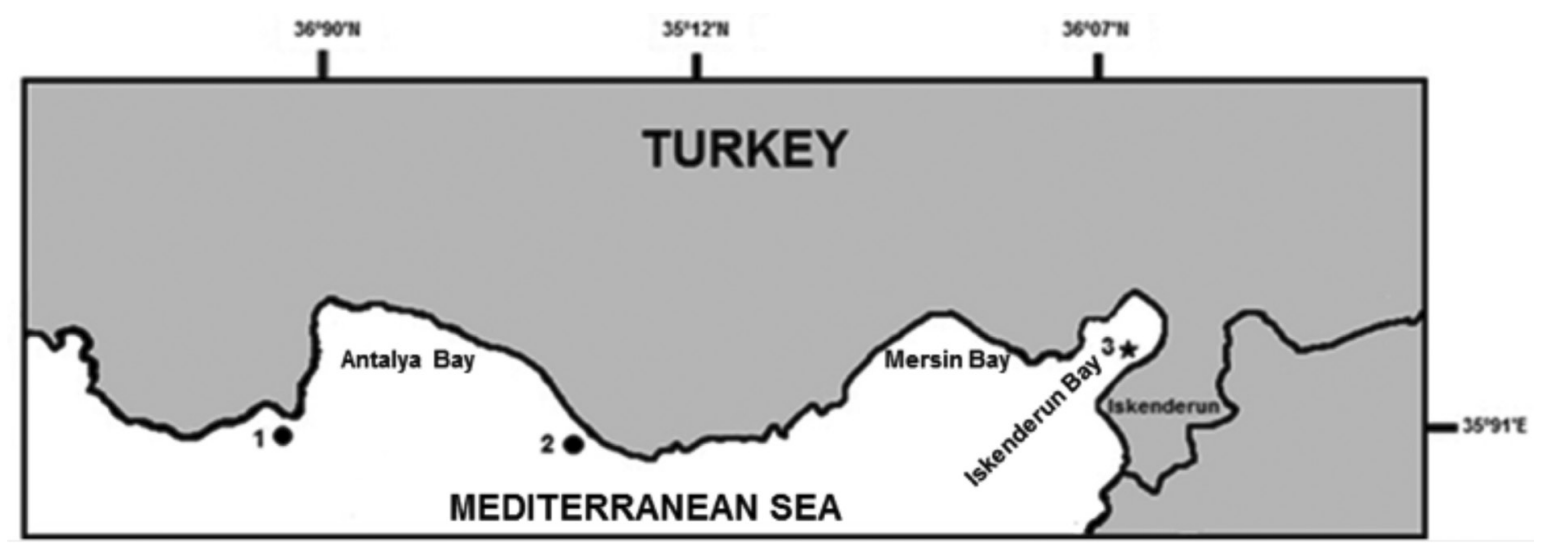

Fig. 1. Sampling location ( $\star$ ) of Porpita porpita from the Iskenderun Bay in the present study (3). •; previous records 1 (Forbes, 1844); 2 (Saygin, 2017) 
2). The presence of a disc in the middle of $P$. porpita helps to float in the water. The blue button ingests prey and its ingredients along with sea water by mouth. The other part is known as hydroid colony which has bright color tentacles. The tentacles and float help to move along and through the water body (RAMANIBAI et al., 2014).

\section{RESULT AND DISCUSSION}

In recent years, new arrivals and establishment of non-indigenous jellyfish species in the Turkish Mediterranean waters are increasing (ÇEVIK et al., 2006; ÖZGÜR \& ÖZTÜRK, 2008; TURAN et al., 2010; ÇEVIK et al., 2011; TURAN et al., 2011; BROTZ \& PAULY, 2012; GÜRLEK et al., 2013; ERGÜDEN et al., 2014; GÜLŞAHIN et al., 2016), this may be attributed to the increasing global warming trend of Mediterranean waters (BIANCHI, 2007).

The way of entrance of this species in the Mediterranean coast of Turkey has not been elucidate until this time. There is no doubt that the occurrence of this species in the Iskenderun Bay can be related to the temperature increases that characterizes the Mediterranean surface waters and that is probably due to a tendency towards global warming (TURAN et al., 2016). P. porpita may also have entered the Mediterranean coasts of Turkey by water currents.

In conclusion, the present paper reports the first occurrence of the new hydrozoan species from the Iskenderun Bay in the northeastern Mediterranean coast of Turkey. It's possible blooms in the area may adversely affect the fish populations and fisheries. Therefore, surveys in this region or in the Mediterranean Sea must be carried out.

\section{ACKNOWLEDGEMENTS}

The study was supported by the Ministry of Agriculture and Rural Affairs Turkey (TAGEM16/AR-GE/21) coded project.

\section{REFERENCES}

BIANCHI, C.N. 2007. Biodiversity issues for the forthcoming tropical Mediterranean Sea. Hydrobiologia, 580: 7-21.

BROTZ, L. \& D. PAULY. 2012. Jellyfish populations in the Mediterranean Sea. Acta Adriat., 53(2): 211-230.

CALDER, DR. 1988. Shallow-water hydroids of Bermuda: The Athecate. Life Sci. Contrib., R. Ont. Mus., 148: 1-107.

CHOWDHURY, M.S.N., S.M. SHARIFUZZAMAN, S.R. CHOWDHURY, M. RASHED-UN-NABI \& M.S. HOSSAIN. 2016. First record of Porpita porpita (Cnidaria: Hydrozoa) from the coral reef ecosystem, Bangladesh. Ocean Sci. J., 51(2): 293-297.

ÇEVIK, C., O.B. DERICI, F.ÇEVIK \& L. ÇAVAS. 2011. First record of Phyllorhiza punctata von Lendenfeld, 1884 (Scyphozoa: Rhizostomeae: Mastigiidae) from Turkey. Aquat. Invasions, 6 (Supplement 1): 27-28.

ÇEVIK, C., I.L. ERKOL \& B. TOKLU. 2006. A new record of an alien jellyfish from the Levantine coast of Turkey. Cassiopea andromeda (Forsskal, 1775) [Cnidaria: Scyphozoa Rhizostomea]. Aquat. Invasions, 1(3): 196197.

DEIDUN, A. 2010. Notes on the recent occurrence of uncommon pelagic "jellyfish" species in Maltese coastal waters. Naturalista Sicil., S. IV, XXXIV(3-4): 375-384.

ERGÜDEN, D., C. TURAN, ÇEVIK C. \& N. UYGUR. 2014. First occurrence of the hydrozoan Geryonia proboscidalis (Forskål, 1775) in the northeastern Mediterranean coast of Turkey. J. Black Sea/Medit. Environ., 20(2): 147151.

FORBES, E. 1844. Report on the Mollusca and Radiata of the Aegean Sea, and on their distribution, considering as bearing on geology. In: Report of the 13th Meeting of the British Association for the Advancement of Science 13, 130-193.

FREDRICK, S.W. \& S. RAVICHANDRAN. 2010. Anti microbial activity of the Cnidarian Blue Button Porpita porpita (Linneaus, 1758). Middle-East J. Sci. Res., 5(5): 355-358. 
FURFARO, G., A. DI GIULIO, C. MANTONI \& P. MARIOTTINI. 2017. On the occurrence of Porpita porpita in the Tyrrhenian Sea: COI and ITS2 DNA barcoding identification. Spixiana, 40(1): 138.

GERSHWIN, L.A., W. ZEIDLER \& P.J. DAVIE. 2010. Medusae (Cnidaria) of Moreton Bay, Queensland, Australia. Mem. Queensl. Mus., 54(3): 47-108.

GUERRERO, E., J.M. GILI \& A. SABATÉS. 2016. Planktonic cnidarians in the neustonic layer: their diversity and abundance off the Catalan coast (NW Mediterranean). 5th International Jellyfish Bloom Symposium, Barcelona, Spain, p. 79.

GUL, S. \& C. GRAVILI. 2014. On the occurrence of Porpita porpita (Cnidaria:Hydrozoa) at Pakistan coast (North Arabian Sea). Marine Biodiversity Records, 7: 1-3.

GÜlŞAHIN, N., M. ÇELIK, C. TURAN \& C. ATEŞ. 2016. First record of the hydrozoan Oceania armata Kölliker, 1853 from Turkey. Zool. Middle East, 62(2): 187-188.

GÜRLEK, M., D. YAĞLIOĞLU, D. ERGÜDEN \& C. TURAN. 2013. A new jellyfish species in the Turkish coastal waters - Aequorea forskalea Péron \& Lesueur, 1810 (Cnidaria:Hydrozoa). J. Black Sea/Medit. Environ., 19(3): 380384.

KOUSTENI, V., R. BAKIU, A. BENHMIDA, F. CROCETTA, V. DI MARTINO, A. DOGRAMMATZI, N. DOUMPAS, S. DURMISHAJ, I. GIOVOS, M. GÖKOĞLU, M. HUSEYINOGLU, C. JIMENEZ, S. KALOGIROU, P. KLEITOU, L. LIPEJ, A. MACALI, A. PETANI, S. PETOVIĆ, E. PRATO, R. FERNANDO, Y. SGHAIER, B. STANCANELLI, S. TEKER, F. TIRALONGO \& D. TRKOV. 2019. New Mediterranean Biodiversity Records 2019. Med. Mar. Sci., 20(1): 230-247.

LILLO, A.O., F. TIRALONGO \& E. TONDO 2019. New

Records of Porpita porpita (Linnaeus, 1758)

(Cnidaria: Hydrozoa) in the Mediterranean Sea. NESciences, 4(3): 293-298.

LINNAEUS, C. 1758. Tomus I. Syst. nat., ed. 10.

Holmiae, Laurentii Salvii: (1-4), 1-824.

MAMISH, S., H. DURGHAM \& S. IKHTIYAR. 2019.
First record of Porpita porpita LINNAEUS, 1758 (Cnidaria, Hydrozoa) on the Syrian coast of the eastern Mediterranean Sea. SSRG - IJAES, 30(20): 47-50.

MEINKOTH, N.A. 1981. The Audubon Society Field Guide to North American Seashore Creatures. Alfred A. Knopf, New York: 364 pp.

ÖZGÜR, E. \& B. ÖZTÜRK. 2008. A population of the alien jellyfish, Cassiopea andromeda (Forsskal, 1775) [Cnidaria: Scyphozoa: Rhizostomea] in the Oludeniz Lagoon, Turkey. Aquat. Invasions., 3: 423-428.

PANDYA, K.M., K.V. PARIKH, C.S. DAVE \& P.C. MANKODI. 2013. Occurrence of Hydrozoans from the saurashtra Coast of Gujarat, India. Res. J. Mar. Sci., 1(4): 1-3.

RAMANIBAI, R., S. GOVINDAN \& T. BALAKRISHNAN. 2014. Notes on the occurrence of Porpita porpita (Blue button) from Pulicat Lagoon. J. Res. Biol., 4(7): 1487-1490.

SAYGIN, Ö. 2017. On the occurrence of blue button, Porpita porpita (Cnidaria: Hydrozoa) from Levantine coast of Turkey. NESciences, 2(2): 33-36.

SCHUCHERT P. 2013. Aequorea forskalea. In: World Hydrozoa Database. Retrieved from http://www.marinespecies.org/aphia. php? $\mathrm{p}=$ taxdetails\&id $=117270$.

TURAN, C., M. GÜRLEK, D. YAĞLIOĞLU \& D. SEYHAN. 2011. A new alien jellyfish species in the Mediterranean Sea, Aequorea globosa Eschscholtz, 1829 (Cnidaria: Hydrozoa). J. Black Sea/Medit. Environ., 17(3): 282-286.

TURAN, C., N. UYGUR, D. ERGÜDEN, B. ÖZTÜRK \& B. ÖZBALCILAR. 2010. On the occurrence invasive Ctenophore comb jelly Mnemiopsis leidyi A. Agassiz, 1865 from Antakya Bay, the Eastern Mediterranean Sea. Biharean Biol., 4(2): 179-180.

TURAN, C., D. ERGÜDEN \& M. GÜRLEK. 2016. Climate change and biodiversity effects in Turkish Seas. NESciences 1(2), 15-24.

WORMS, Editorial Board, 2018. World Register of Marine Species. Retrieved from http://www. marinespecies.org at VLIZ. 


\title{
Pojava plavog dugmeta Porpita porpita (Linnaeus, 1758) zaljev Iskenderun, sjeveroistočna mediteranska obala Turske
}

\author{
Mevlüt GÜRLEK, Ali UYAN*, Servet A. DOĞDU, Serpil KARAN, \\ Ahmet GÖKÇEN i Cemal TURAN
}

*Kontakt, e-pošta: ali.uyan.mfbe15@iste.edu.tr

\section{SAŽETAK}

Plavo dugme Porpita porpita (Linnaeus, 1758.) prvi je put primijećen u srpnju 2018. u zaljevu Iskenderun, sjeveroistočna obala Mediterana u Turskoj. Ovo je treći zapis ove vrste za tursko more, a prvi je zabilježeni nalaz za zaljev Iskenderun. Prisutnost $P$. porpita na sjeveroistočnoj mediteranskoj obali Turske pokazuje njezino proširenje od sjeverozapadne mediteranske obale (zaljev Antalya) u Turskoj.

Ključne riječi: Porpita porpita, hidrozoa, zaljev Iskenderun, turske morske vode 
